\title{
CLARICE . LISPECTOR EN SUS LIBROS Y EN MI RECUERDO
}

\author{
POR \\ EMIR RODRIGUEZ MONEGAL \\ Yale University
}

No recuerdo exactamente cuándo vi por primera vez el extraño nombre, tan poco brasileño, pero sé que era a principios de los años sesenta, cuando los filmes de James Bond habían popularizado la sigla «Specter» que identificaba una organización terrorista contra la que lucha el superespía británico. Pero sé que la asonancia Lispector/Specter debe haber quedado grabada en alguna área de mi memoria donde pronto se asoció a la imagen visual: una mujer hermosa, de ojos rasgados e insondables, pómulos altos y eslavos, y una boca como una dolorosa herida sensual. La foto y el nombre me anduvieron rondando por un tiempo, bastante antes de que cayera en mis manos su entonces más reciente novela: $A$ maçã no escuro (1961). La leí con interés y un poco de fastidio porque la prosa lenta, exigente, espesa, me obligaba a compartir una angustia existencial que me era ajena: el protagonista padecía la culpa de un crimen que no había cometido, y el lector tenía que cargar esa cruz también. Pero si el tema me abrumaba por sus connotaciones de una religiosidad viscosa, la escritura me hechizaba. Con pocos recursos, usando y abusando de la monotonía y de la obsesión de una narrativa esclava, Clarice Lispector conseguía dominar completamente al lector. Emergí de esa lectura, como de una enfermedad, una fiebre lenta y calma. Busqué más cosas de esa mujer extraña.

Mis siguientes lecturas fueron más fáciles: una novela, A Paixão segundo G. H. (1964), y un cuento, «O ovo e a galinha», que leí en una revista. La novela volvía a aquel mundo de la anterior, pero en una forma más nítida y concentrada. El estilo era el mismo, pero parecía haberse 
hecho más transparente. La culpabilidad, en este caso, era más general y no dependía de un acto, sino de la condición humana. La protagonista sentía la náusea de vivir, el suspenso sobre la nada, y agonizaba como Jesús, pero lo hacía a partir de una experiencia ridícula por su trivialidad: visitar el cuarto de la sirvienta, descubrir allí otro mundo, enfrentarse con una cucaracha, aplastarla. De esas nadas se pasaba a una experiencia límite: al comer la cucaracha, G. H. salía de lo cotidiano y entraba en la fábula de Kafka. El cuento también acudía a una situación trivial: el dilema sobre la prioridad del huevo o la gallina, pero la escritura de Clarice lo convertía en densa meditación poética. Mi admiración por esta narradora, que se me revelaba así, en tres textos, no conoció límites. Por esa fecha había prometido escribir una panorámica de la novela brasileña de este siglo para la revista Daedalus, de Boston, y escogí a Clarice Lispector, junto con João Guimarães Rosa, como los más altos exponentes de la ficción brasileña del medio siglo. Más tarde traduje el artículo para Mundo Nuevo, que entonces dirigía en París (1966), y lo publiqué como introducción a una antología de relatos brasileños, que incluía, naturalmente, "O ovo e a galinha».

Sólo cinco años después tuve ocasión de conocer a Clarice Lispector. De paso por Río de Janeiro, en 1971, y gracias a los cariñosos oficios de la novelista Nélida Piñón, gran amiga de la narradora brasileña, pude visitarla en su luminoso departamento del Leme. El cuarto grande, de paredes blancas, estaba decorado con libros, cuadros, grabados, fotografías y flores. En medio, delgada, hermosa, quieta, contenida, estaba Clarice. Sus ojos se fijaban en uno con una mirada en la que no había tensión ni interrogación ni curiosidad, sino asombro. El asombro ante la infinita multiplicidad del universo, ante el espectáculo inagotable de seres y objetos. Clarice miraba, pero era como si sus ojos fueran la puerta para otro universo, un universo que estaba allí, pero no era del todo accesible. El habitante de aquellos ojos se asomaba apenas. Era posible entender que el mundo interior a que daban acceso esos ojos era infinito. Pero digo mal: no había acceso. Los ojos eran una superficie misteriosa. Borges ha definido al hecho estético como la inminencia de una revelación que no se produce. La primera impresión que dejó Clarice Lispector en mí fue ésa. Que no hubiera acceso, o que el acceso estuviera en otro lado (en sus textos), no me importó. E1 hecho estético, los ojos de Clarice, no era menos cierto. La miraba y la veía cumplir con el ritual sobrio y delicado de toda dueña de casa: ofrecer asiento, una bebida, interesarse por detalles triviales. Pero nada de lo que hacía Clarice podía ser trivial, porque sus gestos tenían otro tiempo, sus palabras otro tono, su mirada otra dimensión. No me acuerdo mucho (esto pasó en el invierno brasileño de 
1971) de qué hablamos exactamente. Pero sé que hablamos de sus libros y, sobre todo, de una novelita policial para niños que había publicado hacía unos años: O misterio de coelho pensante (1967), en que la desaparición del conejo es pretexto para una aventura misteriosa y sin solución.

Si Kafka hubiese escrito para niños, tal vez su novelita sería parecida a ésta. Aunque nadie puede escribir parecido a Clarice. Ya en la época de mi visita, Clarice había sufrido un horrible accidente (un cigarrillo mal apagado incendió la cama en que dormía), y una de sus hermosas manos y una pierna habían sido alcanzadas por el fuego. La manera delicada, firme, pero no ostentosa, con que Clarice usaba aquella mano derecha, mutilada, era también una revelación en suspenso. Todo lo que ella hacía, las referencias a un amigo común, un libro o un cuadro (en una de las paredes un retrato que le había hecho el pintor italiano De Chirico en Suiza), estaban rodeadas de un aura. La visita me conmovió por la simplicidad de recursos: Clarice actuaba en otra dimensión, pero sus artificios eran tomados de lo cotidiano. La magia ocurría en la tarde, a la luz fuerte del invierno carioca que entraba, tamizada, por la enorme ventana. Los instrumentos de sus hechizos eran una taza de café, un cigarrillo, un libro con una dedicatoria simpática y trivial. No era, no, el decorado gótico de la hechicera medieval ni el salón recargado de la seductora del decadentismo. Pero, a plena luz, y sin ninguna parafernalia, Clarice Lispector creaba (como en sus libros) un ámbito de magia y hechicería.

\section{II}

La volví a ver en otras ocasiones en el curso de los años setenta, ocasiones todas discretamente creadas por la amistad de Nélida Piñón. Una vez fue en la casa de la madre de ésta, en una cena íntima en que Clarice podía ser ella misma sin tener que representar el papel de Gran Dama de las Letras Brasileñas que ya estaba siendo forzada a asumir. Entonces, en la intimidad de una conversación de amigos, Clarice se dejaba ir y hablaba de trivialidades. Se reía, y festejaba, sobre todo, las salidas de Pedro Paulo de Sena Madureira, entonces editor literario de Imago y ahora de Nova Fronteira. Incisivo, ocurrente, charmoso (como dicen en el Brasil), Pedro Paulo lograba que Clarice suspendiese por un momento ese diálogo abusivo con el silencio y entrase en la corriente circulatoria de la conversación de todos. Silenciosa, pero vigilante, Nélida sabía cuándo decir algo, cuándo apuntar una frase, para que Clarice tomara pie si por un instante se absorbía demasiado en sí misma.

Otra vez (y ésta sí la recuerdo gráficamente, porque luego supe que 
sería la última) Nélida y yo nos encontramos con ella en la Galería Bonimo, de Río, en una exposición de las extraordinarias telas de María Bonomi. En medio de la algarabía de un vernissage carioca, conseguí conversar un poco con Clarice. Hay una extraña foto de ese momento en que ella y yo estamos enfrentados y de perfil, absortos en una conversación, en medio del mar de cabezas que se disparan en todas direcciones y esta1lan contra las grandes telas del fondo. Era un día de ese invierno, tibio y algo viscoso, que caracteriza tanto a Río en julio o agosto, y estaba lloviendo intermitentemente. Tal vez cansada del ruido, Clarice me pidió que la acompañase a buscar un taxi para volver a casa. Fuimos hasta la avenida Nossa Senhora de Copacabana, una de las más infernales de la infernal Copacabana, y mientras discutíamos sobre la mejor estrategia para conseguir un taxi los días de lluvia y el peligro de los asaltos en las calles mal iluminadas de Río, mi total imprevisión del futuro me hizo conseguir uno casi de inmediato, poner a Clarice en él y despacharla muy contento y con prisa a su destino.

No sabía (siempre nos creemos inmortales y generosamente extendemos esta condición a nuestros amigos) que no la vería más. Tampoco sabía que estaba ya enferma de cáncer y que, unos meses después, el 9 de diciembre de 1977, moriría en el Hospital de la Lagoa Rodrigo de Freitas. Todo esto lo supe mucho más tarde por Nélida, y ya no podía hacer nada. Pero aquella noche de mediados de 1975, en Río, me volví a la Galería muy orondo porque, en un plazo mínimo, había conseguido un taxi para Clarice Lispector.

\section{III}

El inevitable tópico de conversación en aquel último encuentro había sido su asistencia a un Congreso Mundial de Brujería que tuvo lugar en Colombia aquel mismo año. La prensa brasileña se había encargado de destacar la extraña invitación, y a su regreso a Río los periodistas no se cansaban de asombrarse: $10^{\circ}$, que Clarice hubiese sido descubierta por los latinoamericanos (como ellos llaman a los hispanoamericanos, como si Brasil no estuviese en América Latina), y 2..$^{\circ}$ que la novelista brasileña hubiese tenido suficiente sentido de humor para asistir. En realidad, la Clarice de los últimos años era una mujer distinta. Su timidez, su reticencia, su recato frente a toda forma de publicidad habían cedido un poco a la fama, a las solicitaciones del periodismo literario, a la cariñosa presión de amigas como Nélida Piñón y Olga Borelli. Desde 1967 escribía regularmente para un periódico unas crónicas leves que ya estaban reco- 
gidas en un volumen (Visão do esplendor, 1975) o serían recogidas póstumamente (Para não esquecer, 1978). Aceptaba entrevistas, se dejaba fotografiar para los periódicos o filmar para la televisión, participaba en paseatas y otras demostraciones políticas, con astros de la publicidad como el arquitecto Oscar Niemeyer, el psicoanalista Hélio Pellegrino, el cantor Milton Nascimento. Incluso aceptaba participar en mesas redondas, aunque sus apariciones solian ser más misteriosas que oratorias. Por eso no era incongruente que asistiera a un Congreso de Brujería.

La prensa colombiana -me decía Clarice en el vernissage de María Bonino - había insistido mucho en la elegancia de su ropa y la hermosura de su porte (probablemente, pensé yo, no habían leído sus libros). Su participación se limitó a leer el cuento "O ovo e a galinha», texto que fue considerado hermético y que nadie, según Clarice, entendió. Tal vez no fue el hermetismo del cuento lo que despistó a los asistentes, sino la atmósfera de feria, con tienditas en que se vendían amuletos y encantamientos, o con médiums que ejercían a pleno sol su profesión de hechicería. La magia y la brujería de aquel Congreso estaba todo en la mecánica de esas tiendas de gitanos. La de Clarice estaba en otra parte. Su fascinación con el misterio empezaba con ella misma.

\section{IV}

En libros que han aparecido en los últimos años o después de su muerte es posible encontrar huellas de esa leyenda de misterio (y, por qué no, de brujería) que se había formado en torno de ella y que, por fin, ella había aceptado asumir públicamente, con algo de cansancio y una gran elegancia. Una vez trató de definir por qué escribía y llegó a esta formulación: «Escrever é compreender melhor» (entrevista con Renato Cordeiro Gomes, XVII). Al preguntársele, en la misma ocasión, por qué empezó a escribir, qué buscaba, contestó:

Queria escrever alguma coisa qüe fosse tranquiila e sem modas, alguma coisa como a lembrança de um alto monumento que parece mais alto porque é lembrança. Mas queria, de passagem, ter realmente tocado no monumento. Sinceramente, não sei o que simbolizava para mim a palavra monumento. $\mathrm{E}$ terminei escrevendo coisas inteiramente diferentes (Gomes, xvIr.)

La alusión gráfica a los misteriosos cuadros de Giorgio de Chirico o de René Magrittte con esos monumentos nítidamente recortados en plazas 
o ciudades de las que la vida parece ausente o petrificada, está corregida por la precisión que aporta Clarice: no se trata tanto de acordarse de un monumento, o de sentirlo, como de saber qué simboliza la palabra monumento. Si algo siempre supo Clarice es que la literatura (como le decía una vez Mallarmé a Degas) se hace con palabras.

El misterio de la escritura empieza, pues, con el escritor mismo, que no sabe sus símbolos, pero conoce sus palabras. En la misma entrevista advierte:

Escrevendo, tenho observações por assim dizer passivas, tão interiores que se escrevem ao mesmo tempo em que são sentidas, quase sem o que se chama de processo. E por isso que no escrever eu não escolho, não posso me multiplicar em mil, me sinto fatal a despeito de mim.

-A criação artística é um mistério que me escapa, felizmente (Gomes, XVII-XVIII).

El misterio consiste no en escribir (es decir, escoger activamente qué decir y cómo), sino en ser escrito. Ya Borges había señalado que la parte más superflua de la obra literaria es aquella que refleja las intenciones, los propósitos del autor. Para Clarice no hay duda: escribe para ser escrita, y de su escritura surge (para ella) la posibilidad de entenderse mejor. En cuanto al misterio deliberado, el hermetismo de que gustan vestirse muchos colegas, estos recursos son totalmente ajenos a Clarice:

Se às vezes tomo sem querer um ar hermético, é que não só o principal é não mentir o sentimento como porque tenho incapacidades de transpô-lo de um modo claro sem que mentisse -e mentir o pensamento sería tirar a única alegría de escrever. Assim, tantas vezes tomo um ar involuntariamente hermético, o que acho bem chato nos outros. Depois da coisa escrita, poderia eu friamente torná-la menos hermética, menos explicativa? Mas é que respeito um certo tom peculiar ao mistério natural da criação não sustituível (esse mistério) por clareza outra nenhuma (Gomes, XVIII).

Sí, tal vez su condición de auténtica bruja esté en aceptar ser escrita, es decir, ser un médium para el lenguaje que habla a través de ella. Por eso puede agregar en la misma entrevista:

Nem tudo o que escrevo resulta numa realização, resulta mais numa tentativa. O que também é um prazer. Pois nem tudo eu quero pegar. As vezes quero apenas tocar (Gomes, XviII-XIX). 
La palabra prazer en la última cita también es reveladora. Porque, para Clarice, escribir es una actividad eminentemente erótica. En la entrevista citada define así las tres cosas para las que nació:

Nasci para amar os outros, nasci para escrever, e nasci para criar meus filhos. $\mathrm{O}$ «amar os outros» é tão vasto que inclui até perdão para mim, mesma, com o que sobra. As três coisas são tão importantes que minha vida é curta para tanto. (...) Amar os outros é a única salvação individual que conheço: ninguém estará perdido se der amor e ás vezes receber amor em troca. (...) Sempre me restará amar. Escrever é alguma coisa extremamente forte mas que pode me trair e me abandonar: posso um dia sentir que já escrevi e que é o meu lote neste mundo e que eu devo aprender também a parar. Em escrever eu não tenho nenhuma garantia. Ao passo que amar eu posso até a hora de morrer. Amar não acaba. E como se o mundo estivesse à minha espera. E eu vou ao encontro ao que me espera (Gomes, Xv-XvI).

El entronque entre la actividad de escribir y la de amar se remonta a los orígenes mismos de su aprendizaje de la lengua brasileña. Nacida en Ucrania y en el seno de una familia ucraniana, Clarice tenía dos meses cuando los padres se instalan en Alagoas. Por eso esta escritora - una de las más notables que ha producido el Brasil- tuvo que aprender el portugués como lengua extranjera:

Fiz da lingua portuguesa a minha vida interior, o meu pensamento mais intimo, usei-a para as palavras de amor. Comecei a escrever pequenos contos logo que me alfabetizaram, e escrevi-os em português, é claro. (...) Em quanto a meus $r r$ enrolados, estilo francês, quando falo, e que me dão um ar de estrangeira, trata-se apenas de um defeito de dicção: simplesmente não consigo falar de outro jeito. Defeito esse que meu amigo Dr. Pedro Bloch disse ser facílimo de corrigir e que ele faria isso para mim. Mas sou preguiçosa, sei de antemão que nao faria os exercícios em casa. $\mathrm{E}$ alem do mais meus $r r$ não me fazen mal algum. Outro mistério, portanto, elucidado (Gomes, xIv-xv).

Amar/hablar/escribir: la lengua portuguesa, o brasileña, es el ámbito en que Clarice aprende a decir no lo que siente, sino lo que quisiera comunicar; en que decir es ser dicha; en que esribir es ser escrita. Actividad del sujeto que lo convierte en objeto, erotismo solitario que lo devuelve a la circulación erótica universal. En las palabras orales, escritas, en el 
acto de hablar o de escribir, Clarice se entrega y posee a la vez. Por eso el misterio; por eso la luminosa oscuridad, la magia de lo cotidiano.

Vuelvo a verla en su departamento del Leme, aquel día de invierno en que la vi por primera vez, y descubro que en esa luz tamizada, en el dibujo perfecto de su rostro, de sus ojos rasgados y profundos como el lago de Narciso, en su boca sensual y nítidamente perfilada, el misterio de Clarice, el hechizo de Clarice, la brujería de Clarice, alcanzan su totalidad. En un cuento de Borges ( $« \mathrm{E} 1$ inverosímil impostor Tom Castro»), para forzar a una madre lacrimosa a reconocer en el impostor al hijo que había perdido, el negro Bogle abre de par en par las ventanas y deja entrar todo el sol: «La luz hizo de máscara», dice impecablemente Borges. Ahora descubro que la máscara de Clarice estaba hecha de luz aquel día de invierno en Río.

Nota: Abunda el material biográfico sobre Clarice Lispector, especialmente el publicado en los últimos años. La antología de Renato Cordeiro Gomes (con estudio y notas de Amariles Guimarães Hill) contiene una valiosa entrevista: Seleta, de Clarice Lispector (Rio de Janeiro: José Olympio, 1975). También contiene material biográfico e ilustraciones el folleto de la serie, Literatura Comentada: Clarice Lispector, a cargo de Samira Youssef Campedelli y Benjamin Abdala Jr. (São Paulo: Educação, abril 1981). Su gran amiga de los últimos años, Olga Borelli, ha publicado un volumen, Clarice Lispector. Esboço para um possivel retrato, que contiene fotografías, textos inéditos y reminiscencias (Rio de Janeiro: Nova Fronteira, 1981). El mejor estudio de conjunto sigue siendo el de Benedito Nunes: Leitura de Clarice Lispector (São Paulo: Quirón, 1973). Una importante adición a la bibliografía crítica es el libro de Olga de Sá, A escritura de Clarice Lispector, con valioso prólogo de Haroldo de Campos (Petrópolis: Editora Vozes, 1979). 